trol, Prof. D. Gabor's project for the thermionic generation of electricity, one for the design of an infinitely variable speed gear, and the development of interferon, a substance which has the important property of interfering with the reproduction of normal virus and may be of wide utility against virus diseases. Major revenue earning inventions during the year include cephalosporin $C$, tri-iodothyronine, the Emidec 2400 electronic computer, Prof. Wain's selective weedkillers, the Hutchinson-Scarrott pulse height analyser, hecogenin, the carbon monoxide detector, an insecticidal fumer, and a microdensito. meter. The Joint Development Committee, set up with the Department of Scientific and Industrial Research in 1958 to examine development problems of common interest and advise on the way in which particular development contracts should be handled, has considered and advised on some twenty proposals for research and development during the year ; it has proved a useful forum for considering matters of interest to both bodies, ensures that overlapping is avoided, and facilitates the investigation by both bodies of gaps in research and development in both fields.

\title{
ADVISING THE FARMER
}

$\mathrm{W}$ ITHIN the Agricultural Education Association, a new section, the Advisory Methods Section, has recently been formed, and a series of papers were read at a meeting of this section in London on December 8. The general topic was to be a review of investigations in advisory methods : in practice, only one of the three speakers dealt at any length with research which has already been done, though all were concerned to analyse the advisory process with a view to further research.

Mr. T. Moore, of the Ministry of Agriculture in Northern Ireland, was the first speaker. He began, by discussing the ways in which advisers could be most useful to farmers, and gave it as his view that 'trouble-shooting' was not of great value, by comparison with the giving of advice on the broader topic of farm management. This point of view is not uncommon among farm advisers, though the idea that the person providing the advice is better fitted to say what topics he should advise on than the person seeking the advice seems to have some unfortunate implications. If for no other reason, the adviser may well have to appear willing to do some 'trouble-shooting' if he wants to get invited on to certain farms, and successful 'trouble-shooting' in such circumstances may serve to win the farmer's confidence.

Using an arbitrary classification of farmers into three categories, Mr. Moore pointed out that advisers themselves can often learn a lot from the best farmers, that there will be a second group who cannot be helped much, leaving a third group consisting mainly of hard-working farmers who farm mainly by traditional methods. Farmers in this last group are those to whom advisers ean be of most use. $\mathrm{He}$ claimed, too, that the size of his farm is not a satisfactory indication of how receptive a farmer will be to advice, though he gave no statistical data to support his claim. Without such evidence, the claim seems an unlikely one, for nearly all studies of farmers have shown that acreage is by far the most useful criterion for assessing the progressiveness of a farmer.

Commenting on advisory methods, Mr. Moore quoted some Australian data which stated that farmers visit other farms a good deal, and he thought this emphasized the importance the farmer attaches to seeing a technique in operation. Another interpretation of the same data would be that farmers feel that they can obtain an unbiased point of view in discussion with a practising farmer. Mr. Moore also commented on individual advisory visits to farms, and remarked that some people were somewhat sceptical about their value. He felt that pilot farms were useful, particularly where the farm chosen is not very different in size from other farms in the district, and claimed it as essential that the pilot farmer farms at a profit, regardless of the appearance of the farm. There seems to be some degree of conflict here with theories of leadership, since farmers commonly appear to have a favourable opinion of farmers who operate on a larger scale than themselves, though there are also data suggesting that the difference in scale must not be too great.

Mr. A. W. van den Ban talked about research on advisory methods in the Netherlands, where there are now five rural sociologists engaged in such work, two of them doing this as a full-time occupation. This certainly compares favourably with Great Britain, in which there is not even one such person who is employed to do full-time research in rural sociology. Mr. van den Ban discussed the part that different sources of information play in the adoption process, with the mass media coming in at the early stages, followed by 'individual' sources, such as talking with advisers, or with other farmers. He recommended that the adviser should manipulate the sources of information at his disposal so as to ensure that the farmer receives information in this way: in practice, because the mass media normally reach a farmer before the 'individual' sources, this does not seem to be any guarantee that this is the ideal way.

Dutch farmers were, until fairly recent times, on a subsistence economy and this still affects their way of thinking. When a whole group of farmers feel this way, it is made even more difficult for an individual to be progressive, and even such activities as reading a book or visiting a meeting in the daytime may be frowned on by the community.

Mr. van den Ban discussed the various sources of information, including the mass media, which a farmer can readily ignore since advice cannot be adjusted to individual needs, as well as farm visits, usually made by an adviser who lives among the farmers he serves, and who does not have so much more training than the farmers: this may mean that there is no great difference in status between the local adviser and the farmers, a fact which should make communication easier. Psychologists have been giving training courses to advisers, in an attempt to help them to cope with problems of inter-personal relationships, for example the somewhat delicate situation which may develop 
when a young adviser has to tell an experienced farmer, older than himself, how to correct his mistakes.

In the Netherlands, it has been found that most of the progressive farmers have visits from advisers, whereas the traditional ones are less likely to be visited. This is not necessarily bad, as Mr. van den Ban explained, since the traditional farmers may learn from studying what the progressive farmers do. When discussing this, and the more deliberate attempts to promote this type of diffusion process, using pilot farms, Mr. van den Ban pointed out that this mechanism may not operate if the farmer chosen is regarded by others as one who is so skilful, or has such good land, that he is in a different category from themselves. If this occurs, this farmer's example may be ignored because it is felt to be irrelevant to their type of farming.

Mr. van den Ban discussed how farmers who are friends appear to influence each other so that, for example, they are very likely to have the same brand of milking machine. He quoted data to show that farmers felt that attending group discussions had a greater influence on them than attending lectures, and cited data from the United States which appeared to point to the same conclusion. He seemed not to be aware that this American finding has been to some extent discredited by more recent research. Mr. van den Ban concluded by emphasizing the need for directing advisory methods to changing the aims of the community, rather than the aims of individuals, so as not to set the individual in conflict with the community norms.

Mr. H. Burr, of the National Agricultural Advisory Service, gave the last paper. Mentioning the frequently occurring finding that farmers are much influenced by other farmers, Mr. Burr wondered if this could be an artefact due to farmers feeling least damage to their self-esteem by admitting to influences of this kind. This is a fair criticism since these research claims are based on farmers' own reports of what influenced them, though there has been some research recently which shows that farmers will go to a lot of trouble to visit farms where a new technique is being tried, before trying it themselves. With the technique concerned, it seemed likely that a talk with the farmer concerned was being sought, rather than an attempt to learn by seeing the technique in action.

Mr. Burr noted that the National Agricultural Advisory Service as a body strongly favoured the individual advisory visit, but said that some within the Service were trying to 'personalize' group advisory methods, so as to achieve the advantages of both. Mr. Burr also talked about 'leaders', and ways of designating them: self-designation may be misleading and direct-designation, for example, when a pilot farm is chosen by the adviser, has its dangers if the farmer concerned is so different from other farmers that they cannot 'identify' themselves with him. Indirect-designation occurs when farmers are asked to name their leaders, though it is not always easy to be sure that the choice of a farmer whose farm is to be used as a pilot farm, or for a farm walk, does not influence other farmers to regard such a person as a leader. Mr. Burr also pointed out that there are few data to show how much influence such leaders have, nor is it known whether the same farmers are the leaders over a long period. He felt that more should be known about this before the Advisory Service commits itself to using leaders deliberately as an advisory technique.

A lively discussion followed these papers and showed the interest which exists in problems of this type, though, clearly, as the speakers emphasized, much more research is needed. The meeting was, in fact, a most interesting one, and it is to be hoped that this Section of the Agricultural Education Association will sponsor many more. It is heartening to think that a group of people, one of the main tasks of which is to encourage a greater use of scientific advances, should be so concerned to evaluate their own methods of passing on these ideas. D. Sheppard

\section{SWISS SOCIETY FOR NATURAL SCIENCES}

$\mathrm{T}$

HE one hundred and fortieth annual session of the Swiss Society for Natural Sciences was held in Canton Aargau during September 23-25, 1960. By a lucky coincidence the main exhibitions connected with the quincentenary of the University of Basle had been extended and were still on view nearby, including the unique Greek treasures and the remarkable display of the University's history, as well as the more purely scientific attraction of the Oreopithecus exhibits and the gorilla baby, 'Goma', born in Basle Zoo.

The Aargau meeting opened with a visit to the installations of Reaktor $A G$ in a large forest clearing at Würenlingen. Here the first Swiss atomic reactor, Sapphyr, originally shown at Geneva, and a second larger reactor are already available for industrial and research purposes in association with Zurich Technical High School. A third reactor, to be larger again, is in process of construction.

The first general assembly was held in the twelfthcentury town of Zofingen, cradle of the nationwide student society Zofingia since 1819, which has been much enlivened by the colourful quin- quennial celebrations. Here the central president, Prof. G. Töndury (Zurich), in his address of welcome introduced the opening speech of the annual president, Dr. K. Baeschlin (Aarau), on the main theme of the session, "Der Mensch und seine Beziehungen zur Umwelt". The subject fell into four categories : man and the universe ; man and Nature in a geographical sense ; man and animal ; and man and man. The first two were treated by Prof. M. Waldmeier of Zurich ("Die Beziehung MenschWeltall"), and Prof. L. Emberger of Montpellier ("La Relation Homme-Nature") at the first general assembly. The second two, by Prof. O. Koehler of Freiburg in Breisgau ("Die Beziehung Mensch-Tier") and Prof. W. Löffler of Zurich ("Die Beziehung Mensch-Mensch"), were given at the second general assembly, in the now State-owned Castle of Lenzburg, once $(1892-1911)$ the possession of Lady Mildred Bowes-Lyon and her American husband, Aug. E. Jessup, te whom is due the present good condition of the property, maintained after them (1911-56) by the last private owners, the family of Lincoln Ellsworth, the arctic explorer in partnership with Amundsen. 